\title{
Corporate Board Attributes, Bank Audit Quality, Bank Performance and Deposit Money Banks in Nigeria
}

\author{
Bweseh Benjamin Musa $^{1^{*}} \quad$ Munura Maihankali $^{2^{*}} \quad$ Ajiduku Kubuza $^{3^{*}} \quad$ Saman Udi Polycarp ${ }^{4 *}$ \\ 1.Department of Accounting and Finance, University of Agriculture Makurdi, P.M.B 2373, Makurdi, Benue \\ State, Nigeria \\ 2.School of Computing, Robert Gordon University, AB107QB Garthdee Road, Garthdee House, Aberdeen, \\ United Kingdom \\ 3.Department of Accounting, Federal University Wukari, P.M.B 1020 Katsina-Ala Road, Wukari Taraba State, \\ Nigeria \\ 4.Department of Accounting, Federal University Wukari P.M.B 1020 Katsina-Ala Road, Wukari Taraba State, \\ Nigeria
}

\begin{abstract}
Nigeria Deposit Money Banks (DMBs) are the life wires of the Nigerian economy as their contribution to the development and growth cannot be overemphasized; This paper examines corporate board attributes (CBR), bank audit quality (BAQ), and bank performance and DMBs with the aid of an ex-post facto design and sample of listed DMBs as at 2019. Descriptive and inferential statistics were employed in the analysis with the use of statistical packages for social sciences (SPSS, version 23.0). The study revealed that bank board size (BBS) has a negative but significant bank board composition (BBC) and Bank Chief Executive Officer Duality (CEOD) has a positive and significant impact on DMBs and concluded that the implications of CBR (BBC, BBS, and CEOD) are important indicators of $\mathrm{BAQ}$ in evaluating the performance of DMBs. One key recommendation was that the position of the CEO as the chairman of the board should be discouraged among DMBs, and the board size should be kept relatively large so as to reach board conclusions easily and fast, also, to enable and strengthen quality audit among DMBs.
\end{abstract}

Keywords: Corporate Board, Audit Quality, Board Size, Board Composition, Chief, CEO Duality, performance, Deposit Money Banks

DOI: $10.7176 / \mathrm{RJFA} / 12-6-03$

Publication date:March $31^{\text {st }} 2021$

\section{Introduction}

The advocacy of good corporate governance in DMBs is attributed to the adequate and faithful presentation of financial statements by the board of directors to stakeholders which is predicated upon the audit quality of the financial statements. When the audit quality is compromised, it seems natural to expect that unfaithfulness will be common in the financial reporting system. The persistent occurrence of corporate scandals and corporate failures of the modern era seems to be the natural aftermath of unfaithful financial reporting and the absence of quality audits (Adeyemi and Fagbemi, 2010). Thus, Nigeria DMBs has witnessed various degrees of corporate scandals and corporate failures even when it is adjudged by a corporate financial diagnosis like audit, monitoring, and supervision to ensure a sound and prudent system has affected stakeholders' wealth and by extension hurt the entire economy.

The liquidation of DMBs in Nigeria had its root from audit failure, imprudent guidelines, lenders, creditors, and investors attributes (Obiyo and Ezenwa, 2012). The questionable role of bank auditor's in ensuring the quality, reliability, and credibility of the financial report has been a debate; the reason had been that auditor's independence from their clients can be compromised through poor regulation and supervision of the auditing practice. Emphasis on the interest in the corporate governance practices of DMBs in relation to auditing and accountability has increased following the high-profile collapses in the past decade characterized by fraud. The code of corporate governance for DMBs in Nigeria specified that there should be an external auditor of high integrity independence and competence which stems from the need that the various changes in accounting, financial reporting, and auditing were all designed to provide protection to investors. Auditing provides the needed assurance for investors when relying on audited financial statements while Corporate governance concerns all parties interested in the wellbeing of firms to ensure that managers and other insiders take measures or adopt mechanisms that promote accountability.

\subsection{Conceptual Review}

Bank Corporate Board

Bank corporate board comprises the governing body of banks who is responsible for the setting of rules and regulations that affect the operation, and management of Banks specifying the distribution of responsibilities and rights among stakeholders (Gupta, 2015). Bank corporate board is attributed to; Board size, board composition, 
and board chief executive officer duality. The linkage between the corporate board, quality of audit services, and the performance of DMBs may be either formal or informal; Formal linkage is when the board of directors collaborates with management in selecting the external auditor often subject to shareholder ratification while informal linkage is when the board influences audit quality through a commitment to vigilant oversight that may signal the management of banks. The board of directors leads the actions of bank management via corporate board attributes.

Bank board size (BBS) is an important component of board characteristics that affect audit quality and the direction of banks which entails the total number of managers on a bank's board who determine the strength, weakness, and corporate performance.

Beasley, (1996) pointed out that the board size has a material influence on the quality of corporate governance and significantly affects the likelihood of financial statement frauds. Adeyemi and Fagbemi (2010) said, according to Chinese corporate law the number of directors on bank board may be between five to nineteen people while Yuanto, (2003) suggested a board size of five board members but Lawal, (2012) averred that a minimum of seven and a maximum of nine board members. Collett and Hrasky (2005) explained that the board of directors can do their tasks effectively when the board size is not more than seven or eight members.

Bank board composition (BBC) is the proportion of non-executive directors on the board compared to executive directors; Executive directors are inside directors who participate directly in the day to day management of the company while non-executive directors are directors who provide the desired outside eye in ensuring that shareholders' interests are safeguarded (Lawal, 2012). Inside directors are managers and hold current offices in banks while outside directors are managers that have no offices but affiliate with the bank. In order to effectively fulfill their monitoring role, boards of directors must have a degree of independence from management (Dahya and McConnell, 2007). A board is independent if made up of more non-executive directors than executive directors whilst most of the codes for best practices have emphasized the need for a mixed directorship with greater nonexecutive representation, empirical evidence remains conflicting with respect to whether such inclusion significantly induces firm performance. BBC assumes an important role in corporate governance, Owing to the separation of executive directors and non-executive directors who exist to protect the interest of shareholders (Adelopo, 2010). The board of directors is charged with monitoring and disciplining senior management, and therefore assuring the quality of financial reporting and Non-executive directors encouraged more intensive audits as a complement to their own monitoring role while the reduction in agency costs expected through significant managerial ownership (executive directors) resulted in a reduced need for intensive auditing (Adelopo, 2010). Bank chief executive officer (BCED) duality exists when a bank CEO serves as the Chairperson of the board of directors (Gupta, 2015) while BCEO exists when the CEO holds the position of the chairman of the board. Boards with BCEO duality are perceived ineffective because a conflict of interest arises. Lin and Liu (2009) believed the duality of the CEO and chairman roles will improve the mechanisms of monitoring management performance, thereby increasing the possibility of a quality audit.

\subsection{Bank audit quality (BAQ)}

Davidson and Neu (1993) explain that AQ as an auditor's ability to detect and exclude errors and significant violation in the report of net income or losses, similarly, Handan and Musa (2012) avers that AQ expresses the ability of external auditors to collect high-quality evidence to support their professional neutral opinions while Akhalumeh, Agweda, and Ogunkwade, (2017) advanced by saying that it is the ability of an audit exercise to detect material error and fraud leading to material misstatements in the financial statements where such exist and Bedard, Johnstone and Smith (2010) ascertain that AQ is conducted in accordance with GAAS- Generally Accepted Auditing Standards to provide reasonable assurance that the audited financial statement and related disclosures are presented in accordance. Therefore BAQ is the investigative standards that is mandated via independence, technical competence, and experience to eliminated bank-related frauds and ensure prudent operations and high performance. IAASB (2014) identifies three elements that contribute to audit quality as relate bank operation that comprises inputs, processes, and outputs at engagement.

Inputs attribute exhibiting appropriate values, ethics, and attitudes, sufficiently knowledgeable, skilled, experienced and have sufficient time allocated to perform the audit work while the process is attributed to applying a rigorous audit process and quality control procedures that comply with laws, regulations and applicable standards and outputs attribute quality audits result that is useful and timely.

\subsection{Bank Performance}

Zeitun and Tian (2007) observe that performance is a controversial issue in the financial strategy of banks due to its multi-dimensional meanings. Nga'anga and Nyonges (2012) as cited in Akinniy et al (2016) asserted that performance is an indicator of the success and health of the service industry within a specific period in time. Performance is aimed at meeting the interest of various stakeholders through effective and efficient operating activities such as increase turnover and efficient non-current asset utilization (Terzungwe and Abdulateef, 2016). 
Performance measures are financial-based (accounting-oriented) or Non-Financial based (marketing-oriented). Financial Performance measures maximization of profit on assets and maximization of shareholders' benefit which are core to banks' effectiveness (Ravi 2020).

Mishkin (1992) as cited in Lisa ad Sandy (2016) argues that the financial performance of an institution can be measured in various ways including Return on Investment, Return on Equity, Return on Asset as well as an estimation based on value addition. Barbosa and Louri (2005) are of the view that financial measurement is one of the tools which indicate the Strength, Weakness, Opportunities, and Threats in respect of banks but Ongore and Kusa (2013) aver that Poor financial performance of DMBs can lead to failure and financial crunch which have undesirable impacts on the economic growth. Singh et al (2010) observe that performance measurement focuses on two factors: those that relate to results and those which relate to the determinate of the result.

Shehu (2011) opines that Bank growth, size, age, risk assets quality, human resources are attributes to the improvement of a firms' financial performance. However, Banks with these attributes are still shrinking and battling to survive, while some are collapsing, it may be possible that the right attributes are not identified. Bank performance is influenced by internal and external factors. Athanasoglou et al (2005) explain that the internal factors include bank size, capital, management efficiency, and risk management capacity while the external factors are the macroeconomic variables such as interest rate, inflation, and economic growth.

\subsection{Deposit Money Banks (DMBs)}

Deposit Money Bank was adopted for all Commercial and Merchant banks operating in Nigeria during the universal banking era of 2001 that deals in retail banking and sources it funds from intermediation processes; interest is paid on the intermediation process, thusly interest on bank deposit is at minimal in Nigeria but interest on charged on lending is high. Currently, there are sixteen DMBs with regional, national, and international authorization in Nigeria as listed on NSE. Ndifon and Sackey (2014) averred that DMBs owe financial intermediation responsibilities to the communities which must be efficiently delivered to retain the confidence of their clients. DMBs provides an efficient payment system, facilitating the implementation of monetary policies, protect depositor fund, encourage competition and protection against systemic risk. DMBs tend to have wielded tremendous influence on the nation's financial landscape which makes them relevant in the focus of monetary authorities in the task of managing the country's economy and are central in financing economic activity. Ajugwe (N. d.) explains that the major players in the financial system are the DMBs; they are paramount in the mobilization of funds thereby enhancing the growth and development of the Economy. Hassan and Abdel-Hameed (2008) aver that the performance of Nigerian DMBs is essential for managerial and regulatory purposes, Corporate board attribute, audit quality affect the financial performance of DMBs therefore, For DMBs to be efficient, they must be audited, regulated and supervised (Dauda, 2015).

\section{Theoretical Framework}

Agency theory was developed by Jensen and Meckling (1976) in an effort to address limitations that affect the relationships and interesting conflict between principals and agents; bank owners lack reasons to believe their managers because of information asymmetries and contradictory motive, thusly, how these are tapped for the purpose of governing a corporation to realize its goal is bridged. Hence, Shareholders hire the managers to control the finances of banks by making them productive, there is bound to be a challenge where the managers feel their efforts are not well rewarded whereas the shareholders might feel that the managers are employees whose reward should only be income for services rendered (Bamberg and Spremann, 1987).

Stakeholder theory was formulated by freeman (1984) in an argument that there are other parties involved in ensuring objectivity other than the owners of a bank; these stakeholders could be individuals or groups who have an interest in the growth of the firm. The stakeholders' theory suggested a restructuring of the theoretical perspectives that extends beyond the owner manager-employee position and recognizes the numerous interest groups and that if organizations want to be effective, they will pay attention to all and only those relationships that can affect or be affected by the achievement of the organization's purpose.

\subsection{Empirical Review}

Paul, Fancy, and Zaccheaus (2017) assessed corporate board characteristics and audit quality in Nigeria with the aid of Regression analysis to estimate the model using STATA. Findings revealed a significant positive relationship between corporate board characteristics and audit quality. The implication of the finding is that such variables as firm size, the board size, board composition, financial leverage, and firm profitability are important indicators of audit quality among Nigerian firms.

Ejeagbasi, Nweze, Ezeh, and Nze, (2015) investigate the relationship between corporate governance and quality of auditor's report evidenced Nigerian Banking Industry, the study adopts an ex-post facto research design for historic data of Eleven listed DMBs. Correlation analysis was applied covering seven years to 2014 which was regarded as the post-corporate governance period. The Analysis showed that board composition has a negative and 
insignificant relationship with audit quality, separation of the roles of the chief executive officer from that of the chairman of the board, the board size, and composition of the audit committee has a positive and significant relationship with audit quality.

Marjene, Rabah and AzhaarLajmi, (2013) studied the impact of Board Characteristics and external audit quality for the period 2003-2007 for sixty-six Belgian listed companies on the Euronext Brussels Stock Exchange. Audit quality is measured using an index for that- index of audit quality (IQAUD). IQAUD was determined by using the "step by step" method of Cronbach's alpha coefficient. The results of the regression model using panel data confirm that external audit quality and board characteristics are complementary mechanisms.

Hassan and Bello (2013) studied the effect of audit firm attributes on earnings quality of listed consumer goods firms in Nigeria. The study used 13 firms as sample size, Earnings quality is the proxy for the dependent variable which modified Jones Models was used to measure earnings management while industry specialized audit, audit compensation; audit tenure, and audit firm types are the independent variables. The study employed OLS regressions as a tool for analysis. The result shows that industry specialized auditor and audit firm type have a significant positive influence on earnings quality of sampled firms, audit tenure and audit compensation have no significant influence on earnings quality of the firms.

Dangana, (2014) studied audit firms' attributes on financial reporting quality of quoted building material firms in Nigeria, The study used four firms and employed correlation research design for the period of ten years. OLS multiple regression techniques were employed in the analysis of the panel data collected, The study used audit compensation and audit firms independence and financial quality which Jones models was used for the measurement. The study showed that audit compensation and audit firm independence have a significant positive impact on the financial reporting quality of sampled firms at a $99 \%$ confidence level.

Sylvester and Eyesan (2017) studied audit quality and earnings management in Nigerian DMBS with a sample of 18 quoted banks as of 2010, Data was gathered for the periods 2005 to 2010. The cross-sectional year-by-year regression analysis was used to analyze the data. Audit quality was measured using audit fees and auditor change, and abnormal loan loss provision was used to measure earnings management. The results show that both audit fee and auditor change were positively and significantly related to abnormal loan loss provision.

\section{Methodology}

The paper employed ex-post facto data in determining the influence of Corporate Governance Attribute, Audit Quality, and the performance of Listed Deposit Money Banks in Nigeria between 2010 and 2017 with the aid of Descriptive and inferential statistics.

The regression model for the study specified as:

$\mathrm{AQ}=\mathrm{f}(\mathrm{BS}, \mathrm{BC}, \mathrm{CEOD}, \mathrm{e} 1)$

$\mathrm{AQ}=\beta 0+\beta 1 \mathrm{BS}+\beta 2 \mathrm{BC}+\beta 3 \mathrm{CEOD}+\mathrm{e} 1$

Where:

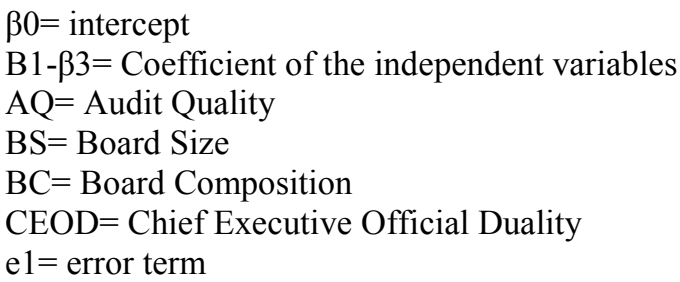


Table 1

List of Quoted DMBs operating in Nigeria as at September 30, 2018

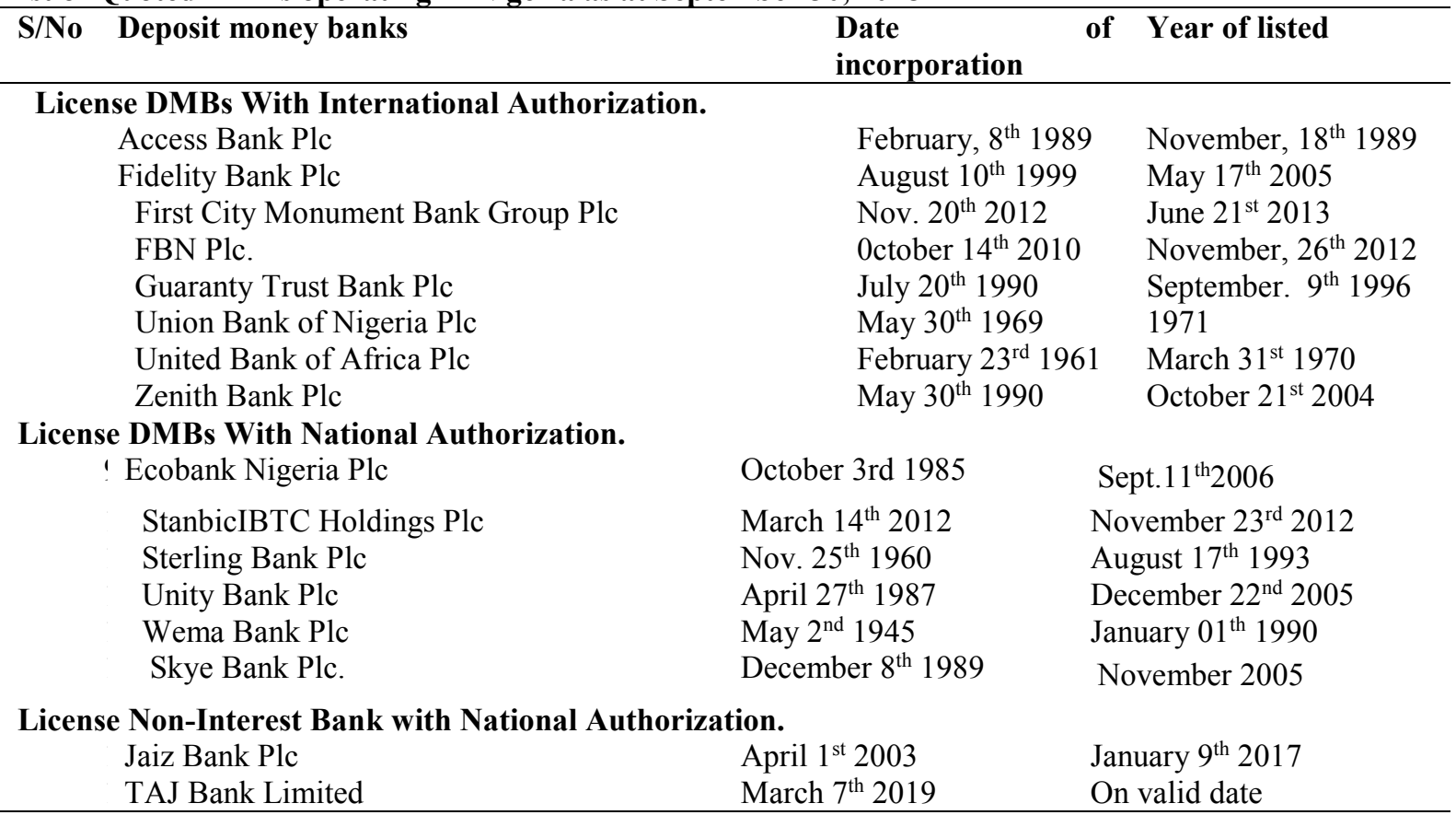

Source: documentary source, 2019.

\section{Result and Discussion}

\subsection{Descriptive statistics}

The descriptive statistics employed were mean and standard deviation.

Table 2 Descriptive statistics

\begin{tabular}{llll}
\hline & Mean & Std Deviation & $\mathrm{N}$ \\
\hline Bank Asset Quality & 8.7500 & 0.46291 & 8 \\
Bank Board Size & 138.6250 & 5.09727 & 8 \\
Bank Board Composition & 9.6250 & 0.51755 & 8 \\
Bank Chief Executive Officer Duality & 1.6250 & 0.74402 & 8 \\
\hline
\end{tabular}

Source: SPSS Output, 2019

Table 2 revealed that bank audit quality has a mean of 8.7500 and a standard deviation of 0.46291 while BBS, $\mathrm{BBC}$ and CEO duality has a mean of $138.6250,9.6250$ and 1.6250 respectively and a standard deviation of $5.09727,0.51755$ and 0.74402 respectively.

Correlation analysis

Table 3 present the correlation results between BAQ, BBS, BBC, and CEO duality.

Table 3 Correlation Result.

\begin{tabular}{lllll}
\hline & $\boldsymbol{B} \boldsymbol{A} \boldsymbol{Q}$ & $\boldsymbol{B B S}$ & $\boldsymbol{B B C}$ & $\boldsymbol{C E O D}$ \\
\hline $\boldsymbol{B} \boldsymbol{A} \boldsymbol{Q}$ & 1 & & & \\
$\boldsymbol{B} \boldsymbol{B} \boldsymbol{S}$ & .015 & 1 & 1 & \\
$\boldsymbol{B} \boldsymbol{B} \boldsymbol{C}$ & .745 & .426 & -.419 & 1 \\
$\boldsymbol{C E O D}$ & .104 & -.570 & & \\
\hline
\end{tabular}

Source: SPSS Output (2019).

Table 3. revealed that quality of audit of a DMBs is associated with the number of directors that make up the board are subjected to the view of all members of the board of directors and This entails that the proportion of nonexecutive directors to executive directors has a high influence on quality of a firm's audit, thusly, for a quality bank audit to be ensured in DMBs in Nigeria, the number of non-executive directors should be kept at balance and Chief executive officer duality indicating that when the board chairman is also the banks chief executive officer audit quality would increase and strengthen.

\subsection{Regression Analysis}

The result of regression analysis is show in table 4. 
Table 4 Regression result.

\begin{tabular}{llllll} 
Variable & Std. Error & Beta & T & Sig. & Remark \\
\hline (constant) & 4.012 & - & .469 & .664 & - \\
BBS & .027 & -.168 & -.570 & .599 & Negative but significant. \\
BBC & .238 & .993 & 3.738 & .020 & Positive but significant. \\
CEO duality & .182 & .423 & 1.446 & .222 & Positive but significant. \\
R $^{2}$ & & & .782 & & \\
Adjusted R & & & .618 & & \\
F- Ratio & & 4.778 & & \\
P- Value & & $.083 \mathrm{~b}$ & & \\
\hline
\end{tabular}

Source: SPSS output (2019).

Table 4 revealed The regression results which indicate that model has an F-ratio of 4.773 with p values of 0.083 . The p-value is significant at $90 \%$ indicating that the model is fit; The R-square of 0.782 shows the variation in BAQ due to changes in the independent variables that's the $78.2 \%$ variation in BAQ was due to changes in BS, $\mathrm{BC}$ and CEO duality. This indicates that BS has a beta value of -.1 68, a t-value of -.570, and p-value of .599, and a negative but significant on BAQ in Nigeria DMBs. Furthermore, it's showed that BBC has a beta coefficient of 0.993, a t-value of 3.738, and p-value of .020, and a positive significance on BAQ in Nigeria DMBs. The analysis result also shows that CEO duality has a beta coefficient of 0.423 , a t-value of 1.446 , and p-value of 0.222 which revealed that CEO duality has a positive and significant impact on audit quality in Nigeria DMBs.

\section{Discussions of Findings}

The study avers that BBS has a negative association but a statistical influence on BAQ which may negatively affect the performance of DMBs in Nigeria, and also revealed that BBC has a strong relationship and significant impact on audit quality in Nigeria DMBs. This entails that BAQ is strengthening when the number of nonexecutive directors is balanced in proportion with the number of executive directors in a board. Similarly, CEO duality has a significant positive impact on BAQ which will positively affect the performance of Nigeria DMBs. This means that the separation of the position of the chairman of the board from the firm chief executive officer has a statistical influence on the ban audit quality.

\section{Recommendations}

Recommendations based on the findings recommend that;

i. The BBS should be kept relatively large so as to reach board conclusions easily, fast, and strengthen audit quality among Nigeria DMBs.

ii. The $\mathrm{CBN}$ code that states the role of the board is to "retain full and effective control of the banks and monitor executive management" has to be followed properly at least up $80 \%$.

iii. The position of the CEO as the chairman of the board should be discourage among DMBs so as to prevent the superiority of one person over the firm who may also influence decisions as it pleases.

iv. The composition of the board of directors should be strictly adhered with, for its contribution to corporate governance brings best practices and ideas about internal control, risk management processes and quality audit.

\section{References}

Adams, R.B. and Ferreira, D. (2009). Women in the boardroom and their impact on governance and performance . Journal of Financial 54 Economics, 94 (2), 291309.

Adelopo, I. (2010). The impact of corporate governance on auditor independence: A study of audit committess in UK listed companies.

Adeyemi, S. B., Fagbemi, T.O. (201 0). Audit quality, corporate governance and Firm Characterisic in Nigeria. International journal of Business andManagement 5 (5), 169-179.

Al-Matari, Y. A., Al-Swidi, A. K., Bt Fadzil, F. H and Al-Matari E. M. (201 2). Board of Directors, audit committee Characteristics and performance of Sandi Arabia listed Companies. Int. Rev. Manage. Market. 2(4):241 -251.

Asika, N. (2005). Research Methodology in Behavioral Sciences: Lagos" Longman Publishing Limited Banks and Other Financial Institutions Act 1991.

Bansal, N., and Sharma, A. K. (201 6). Audit committee, corporate governance and firm performance: empirical evidence from India. International journal of Economics and finance, 8(3), 1-3

Beasley, M. S. and Petroni, K. R. (2001 ). Board Independence and AuditFirm Type, Auditing, 20:97-114.

Bhugat, S., and Black, B. (2002).The non-correlation between board independence and long term firm performance. Journal of Corporation Law, 27 (2),231-274.

Blue Ribbon Committee. (1999). Report and recommendations of the Blue Ribbon Committee on improving the 
effectiveness of corporate audit committee, New York: NYSE and NASD.

CBN (2006). CBN Code of Corporate Governance for Banks in Nigeria Post Consolidation, Nigeria Abuja.

Chalaki P, Didar H, Riahinezhad M (201 2). Corporate governance attributes and financial reporting quality: Empirical evidence from Iran. Int. J. Bus. Soc. Sci. 3(1 5):225-229.

Collett P, Hrasky S (2005). Voluntary disclosure of corporate governance practices by listed Australian firms: Corporate Governance. J. Int. Rev. 1 3(2):1 88-1 96.

De Angelo LE (1981). Auditor size and audit quality. J. Account. Econom. 553:183-199.

De Angelo LE (1981a). Auditor independence "Low Balling" and disclosure regulations. J. Account. Econom. 3(2):1 1 3-1 27

Dechow, P.M., Sloan, R.G., \& Sweeney, A.P. (1 996). Causes and consequence of earning manipulation: An analysis of firms subject to enforcement action.....

Ditropoulos, P. \& Asteriou, D. (201 0). The Effect of Board Composition

Ejeaggbasi, G, Nweze, A., Ezeh, E., and Nze, D. (201 5). Corporate governance and Audit Quality : Evidence from the banking industry. European journal of Accounting, Auditing and Finance Research Vol. 5 (1) pp18-39

Enofe, A. O., Ediae, O. O., and Ejiemen, C. O. (2013). Audit Quality and Auditor Independence in Nigeria: An Empirical Evaulation journal of finance and accounting 4(11).

Fama, E. F. and Jensen, M. C. (1 983). Separation of Ownership and Control. Journal of Law and Economics, XXVI: $301-325$.

Freeman, R. E. (1984). Strategic Management: A Stakeholder Approach. Boston, Pitman.

Gelaneh, A.(2011). The Impact of Extended Audit Tenure on Auditors Independence and Audit Quality: An Empirical Study on Ethiopian private audit firms. Addis Ababa University.

Gupta, S.K. (2015). Corporate governance practices of Developing Nations: An empirical study of India. World J. Soc. Sci. $5(1): 51-56$.

Hassan, S. U \& Bello A. (201 3). Firm characteristics and financial reporting quality of listed manufacturing firms in Nigeria. Int. J. ccount. Bank. Manage. 1 (6):4, 7-63. IAASB CAG

Agenda, R. (201 1). Agenda Item F.1 , Audit Quality Thought P C IK C K IlK C IK IlC IIK C 1C IKenieaoacteenrd,prgeno,rarEsIatAh.iA,toieS\&pnBGCasZalotgarRvPruadecpkrevtrnou.iearow nhc,ai,1enA:3d.A.A .A .: 2f7ni08rm055-7p. 9eB9rof.oarmd ance. 56.

Lawal, B. (2012). Board Dynamics and Corporate Performance: Review of Literature, and Empirical Challenges,international journal of economics and finance, vol. 4(1).

Lennox C.S. (1999). Non-audit fees disclosure and audit quality. Eur.Account. Rev. 8(2):239-252

Levitt, A. (1 998). The numbers game. Remarks delivered at the NYU Center for Law and Business. New York, NY, September 28. [Online] Available: http://www.sec.gov/news/speech/speecharchive/1998/spch220.txt on $12 / 10 / 2009$.

Liu, H. and Fong, M. (201 0), "Board characteristics of medium and large Chinese companies", Corporate Governance, Vol. 10 No. 2, pp. 1 63-1 75.

Malek, M. and Che Ahmad, A. (201 2). Director-auditor link and audit quality, in Corporate Governance Practices in Malaysia, Muhamad, Z., Mohd, S R., Malek, M, Senik R Ed. Selangor: Universiti Malaysia. Press, ch. 9, pp. 139157.

Malek, M., and Saidin, S. F. (2013). Audit services fee, non-audit services and the reliability of earnings. International Journal of Trade, Economics and Finance, 4(5), 259.

McConomy, B., and Bujaki, M. (2000). Corporate Governance: Enhancing Shareholder Value. CMA Management,74(8), 1 0-13.

McMullen D.A. (1996). Audit committee performance: an investigation of the consequences associated with audit committees. Auditing: A Journal of Practice \& Theory, 15(1), 87-1 03.

McMullen, D.A., and Raghunandan, K. (1996). Enhancing audit committee effectiveness. Journal of Accountancy, $182,79-81$.

Nehme, R. (2013). Dynamics of audit quality: behavioural approach and governance framework: UK evidence (Doctoral dissertation, Durham University).

Obiyo C.O. and Ezenwa O.T. (2012). The effect of corporate reporting on public confidence: Empirical study of companies in Nigeria. Far East J. Psychol. Bus. 6(2):72-85.57

Okolo, J. U. T. (1 989). The Concept and Practice of Auditing. Lagos, Evans Brother Nigeria Publisher Ltd.

Palmrose, Z. (1988). An analysis of auditor litigation and audit service quality. Account. Rev. 63(1 ): 55-73

Paul Akhalumeh, Fancy A. \& Zaccheaus O. (201 7). Corporate characteristics and audit quality: evidence from quoted firms in Nigeria. Journal of 59-66. Scientific Research and Studies Vol. 4(3), Popoola, S. O. (2011)

Public Oversight Board. (1994). Strengthening the professionalism of the independent auditor. Stamford, CT: POB

Sanda, A. U, Mukaila, A. S \& Garba, T. (2005): Corporate governance mechanisms and firm financial performance in Nigeria. AERC Research Paper, No 1 49. SPSS 23 for Windows Evaluation Version Release 23.0 (2011).

Sylvester E., and Eyesan L. (201 7). Audit quality and Earnings Management in Quoted Nigerian Banks: Journal 
of Accounting, Finance and Auditing. [Online] Available: https://jafas.org/articles/2017-31/1_Audit_Quality_FULL_TEXT.pdf

Wan, Z.W.A., Shahnaz, I., and Nurasyikin, J. (2008). The impact of board composition, ownership and CEO duality on audit quality. Malaysian Accounting Review, 7(2), 1 -22.

Yermack, D. (1996). Higher Market Valuation of Companies with a Small Boards of Directors, Journal of Financial Economics, 40, 2: 1 85-21 2

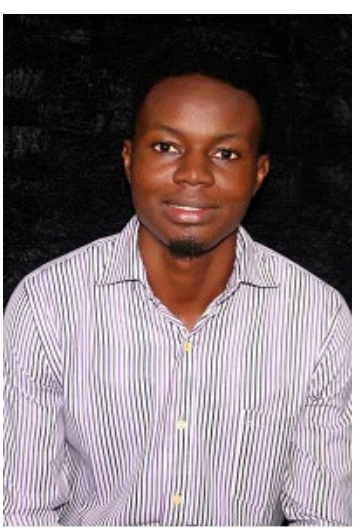

Second A. Munura Maihankali. This author became a member of the Chevening Community in 2020; the British Computer Society in 2021 and the Rotary community in 2021. This author is a Chevening scholar who hails from Nigeria and is currently enrolled for a Masters degree in data science at Robert Gordon University Aberdeen, United Kingdom(2021). This author obtained a Bachelor of Science degree in Computer Science from Benue State University Makurdi, Nigeria(2016). The author's research spans Computing, Banking, and Economics.

He is currently an EDITOR with Carijournals(www.carijournals.org) Washington DC, USA. He has held the positions of :

STUDENT AMBASSADOR at Robert Gordon University Aberdeen, United Kingdom;

IT SPECIALIST/PROGRAMMER at Kwararafa University Wukari, Taraba State, Nigeria;

LECTURER/IT SPECIALIST at Taraba State College of Health Technology Takum, Taraba State Nigeria;

He is an avid writer(poet, novelist) and has featured a number of publications one(Above The Social Drama) of which was the prize winner at the FCMB 2020 National writing contest; his publications encompass:

Musa, B. B., \& Maihankali, M. (2021), "Information Technology - A Veritable Tool For National Development", Journal of Technology and Systems, 3(1), 1-13. [Online] Available: https://carijournals.org/.../index.php/JTS/article/view/511

Maihankali, M.(2020), "Above The Social Drama", [Online] Available: https://flexxzone.fcmb.com/2020/11/above-the-social-drama/

Maihankali, M.(2021), "Blended Learning Experience", [Online] Available: https://rgustudentblog.com/2021/01/27/munuras-blended-learning-experience-during-covid-19/ 